\title{
Extent and duration of Antarctic surface melting
}

\author{
H. JaY ZWALLY \\ NASA/Goddard Space Flight Center Oceans and Ice Branch, Greenbelt, Maryland 20771, U.S.A. \\ STEPHEN FiEgLES \\ Hughes STX Corporation, Greenbelt, Maryland 20770, U.S.A.
}

\begin{abstract}
The extent and duration of surface melting on the Antarctic ice shelves and margins of the Antarctic ice sheet are derived from satellite passivemicrowave data for 1978-87. The occurrence of surface melting in daily maps of $T_{\mathrm{b}}$ is indicated by a marked increase in microwave brightness temperature $\left(T_{\mathrm{b}}\right)$, which is caused by moisture in the near-surface firn. $T_{\mathrm{b}}$ increases of more than $30 \mathrm{deg}$ above the annual-mean $T_{\mathrm{b}}$ are chosen to indicate melting. Most Antarctic surface melting occurs during December and January. The observed melting is correlated with regional air temperatures, but some melt patterns also appear to be related to katabatic-wind effects. The correlations suggest that the surface melting in Antarctica increases about $3.5 \times 10^{6} \mathrm{~d} \mathrm{~km}^{2}$ per degree of summer temperature increase. The surface-melt index (duration times area of melting) calculated for Antarctica is $24 \times 10^{6} \mathrm{~d} \mathrm{~km}^{2}$, averaged over nine summers. The observed inter-annual and regional variability is large. Surface melting was most extensive during the $1982 / 83$ summer $\left(36 \times 10^{6} \mathrm{~d} \mathrm{~km}^{2}\right)$ and least extensive during the $1985 / 86$ summer $\left(15 \times 10^{6} \mathrm{~d} \mathrm{~km}^{2}\right)$. The data indicate a decline in surface melting over the 9 years, but meaningful inferences regarding trends in surface melting are precluded by the large inter-annual variability.
\end{abstract}

\section{INTRODUGTION}

Measurement of surface melting is of interest for studies of glacier dynamics and for monitoring climatic changes in polar regions. Downward percolation of meltwater from the firn surface, followed by refreezing at colder depths, transports heat downward at a much greater rate than thermal conduction and diffusion. Mercer (1978) and Stuiver and others (1981) suggested that enhancement of this melt-freeze process during a "greenhouse" warming could be sufficient to raise the ice shelves to the pressuremelting point throughout, leading to their disintegration. Paterson (1984) considered this process in more detail and concluded that the projected greenhouse warming would not be sufficient to induce disintegration; however, he noted the need for more quantitative data on the meteorological conditions and melting on the shelves.

Under current climatic conditions, surface temperatures remain below freezing over most of the Antarctic ice sheet throughout the year. Some surface melting extends inland from the Ross Ice Shelf onto the ice sheet of Marie Byrd Land (Giovinetto, 1964; Alley and Bentley, 1988). However, in most places on the ice sheet, the dry-snow line lies only a few tens of kilometers inland from the coast or from an ice-shelf grounding line (Giovinetto, 1964). Extensive surface melting usually occurs each year on many of the ice shelves, specifically those in the Antarctic Peninsula, those adjacent to the Amundsen and Bellingshausen Seas, and those along the East Antarctic coast, including the Amery Ice Shelf. Of the major ice shelves, the Ross Ice Shelf has occasional surface melting, but the Filchner-Ronne Ice Shelf lies almost entirely within the dry-snow line (Giovinetto, 1964).

Early measurements of the microwave emission from snow cover on land showed large increases in the microwave brightness temperature $\left(T_{\mathrm{b}}\right)$ as the moisture content in the snow increased above zero (Edgerton and others, 1971). Passive-microwave images of the polar regions, from the ESMR (Electrically Scanning Microwave Radiometer) on the Nimbus-5 satellite, showed large increases in $T_{\mathrm{b}}$ during summer on the percolation zone of Greenland and on the Antarctic ice shelves where surface melting usually occurs (Zwally and Gloersen, 1977). Also, the data showed marked variations in $T_{\mathrm{b}}$ on daily time scales, indicating that the emissivity was changing rapidly in response to changes in the meltfreeze conditions of the surface. Such rapid changes had also been observed in snowpacks during diurnal meltfreeze cycles (Edgerton and others, 1971).

Theoretical calculations of the microwave emission from snow and firn by Chang and others (1975) showed that small amounts of liquid water on the surface of the ice particles significantly changed their dielectric properties, reduced their radiative scattering and increased the microwave emission from the media. Davis and others (1987) compared that model with an alternate model, in which the water is assumed to occur in small menisci between ice spheres. In the models and measurements, the microwave emission drops upon refreezing, because the ability of the ice particles to scatter radiation emitted 
from deeper in the snow or firn is re-established. In addition, during melt-freeze cycles, the average size of the snow grains increases, which increases the radiative scattering and lowers the $T_{\mathrm{b}}$ when the firn is frozen. Therefore, dry firn that has undergone prior melting tends to have a lower $T_{\mathrm{b}}$ than firn that remains continuously dry.

Passive-microwave maps of the ice sheets were first made with data from the ESMR passive-microwave imager on Nimbus-5, which was launched in December 1972 and continued to operate for several years after Nimbus-7 was launched in 1978. However, not all ESMR data were usable, and degradation of the sensor was most serious after 1976. The SMMR (Scanning Multichannel Microwave Radiometer) on the Nimbus-7 satellite collected good-quality data every other day from November 1978 until August 1987 (Gloersen and others, 1992). The next section describes the objective criteria chosen to extract a passive-microwave surface- melt index from satellite $T_{\mathrm{b}}$ data. The derived surfacemelt index describes the spatial and temporal variability of the surface melting.

\section{PHYSICAL BASIS FOR PASSIVE-MICROWAVE SURFACE-MELT INDEX}

As previously noted, the onset of melting produces a marked rise in $T_{\mathrm{b}}$ that is caused by moisture in the nearsurface firn. However, the amount of rise depends on the difference between the emissivity, $\epsilon$, of wet firn and the $\epsilon$ of dry firn. The emissivity of dry firn at $1.5 \mathrm{~cm}$ microwave wavelength varies from about 0.65 to 0.85 (e.g. Zwally, 1977; Zwally and Gloersen, 1977) and is strongly dependent on the firn grain-size. The emissivity of wet firn is about 0.9 and tends to be independent of the grainsize. Therefore, the $T_{\mathrm{b}}$ of dry firn has widely different values in different firn zones, but the $T_{\mathrm{b}}$ of wet firn is

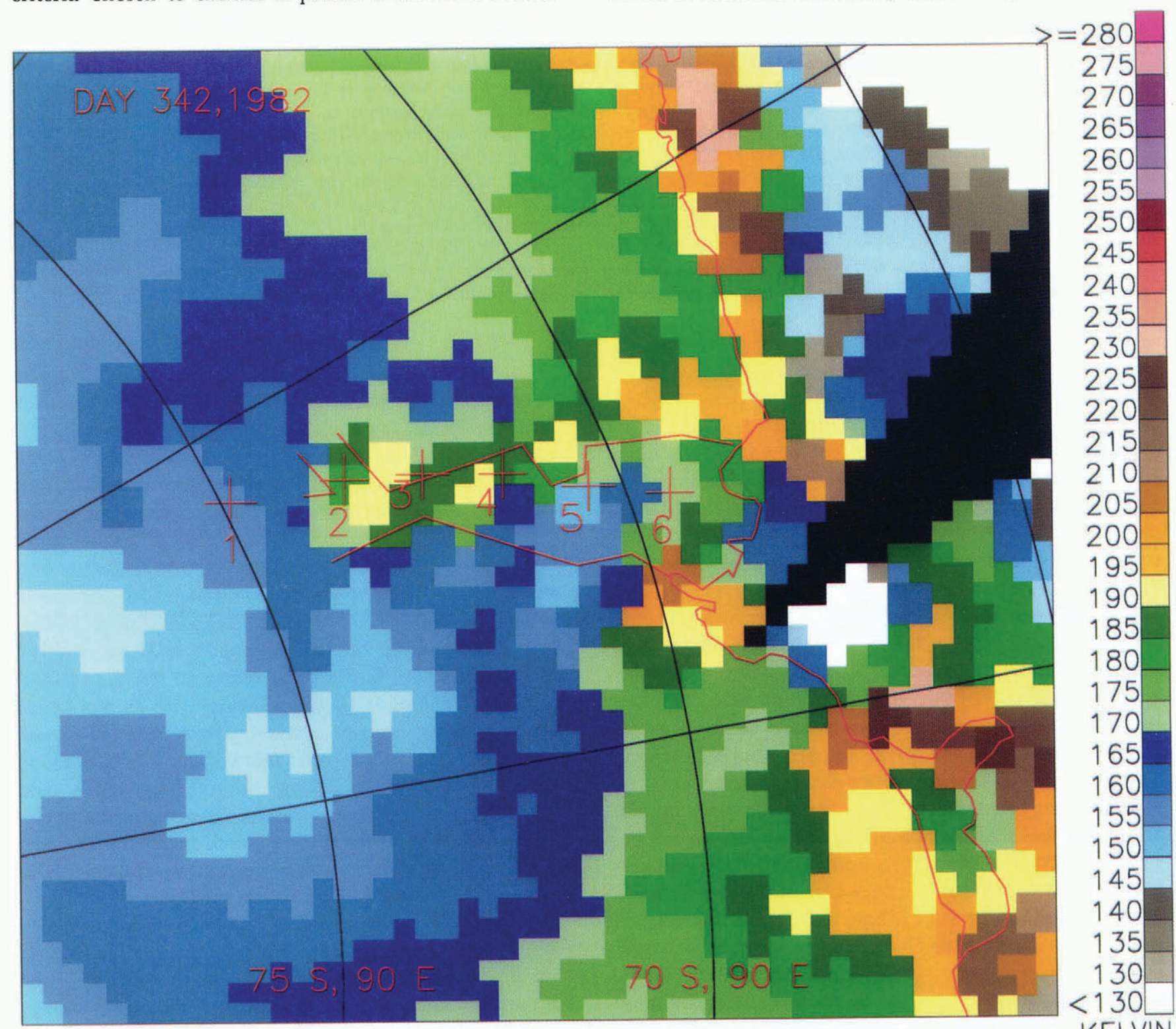

Fig. 1. Microwave brightness temperature from Nimbus-7 SMMR on the Amery Ice Shelf and vicinity on (a) 8 December (day 342), (b) 18 Decomber (day 352), and (c) 28 December (day 362) 1982. On day 352, when surface melting is indicated at points 4 and 6 , the melt patterns may be affected by heating by katabatic winds on Lambert Glacier (points 3 and 4) and Kreitser Glacier and adjacent glaciers (southeastward from point 6). On day 362, surface melting is indicated over the entire ice shelf and inland on the ice sheet to about $1800 \mathrm{~m}$ elevation. 


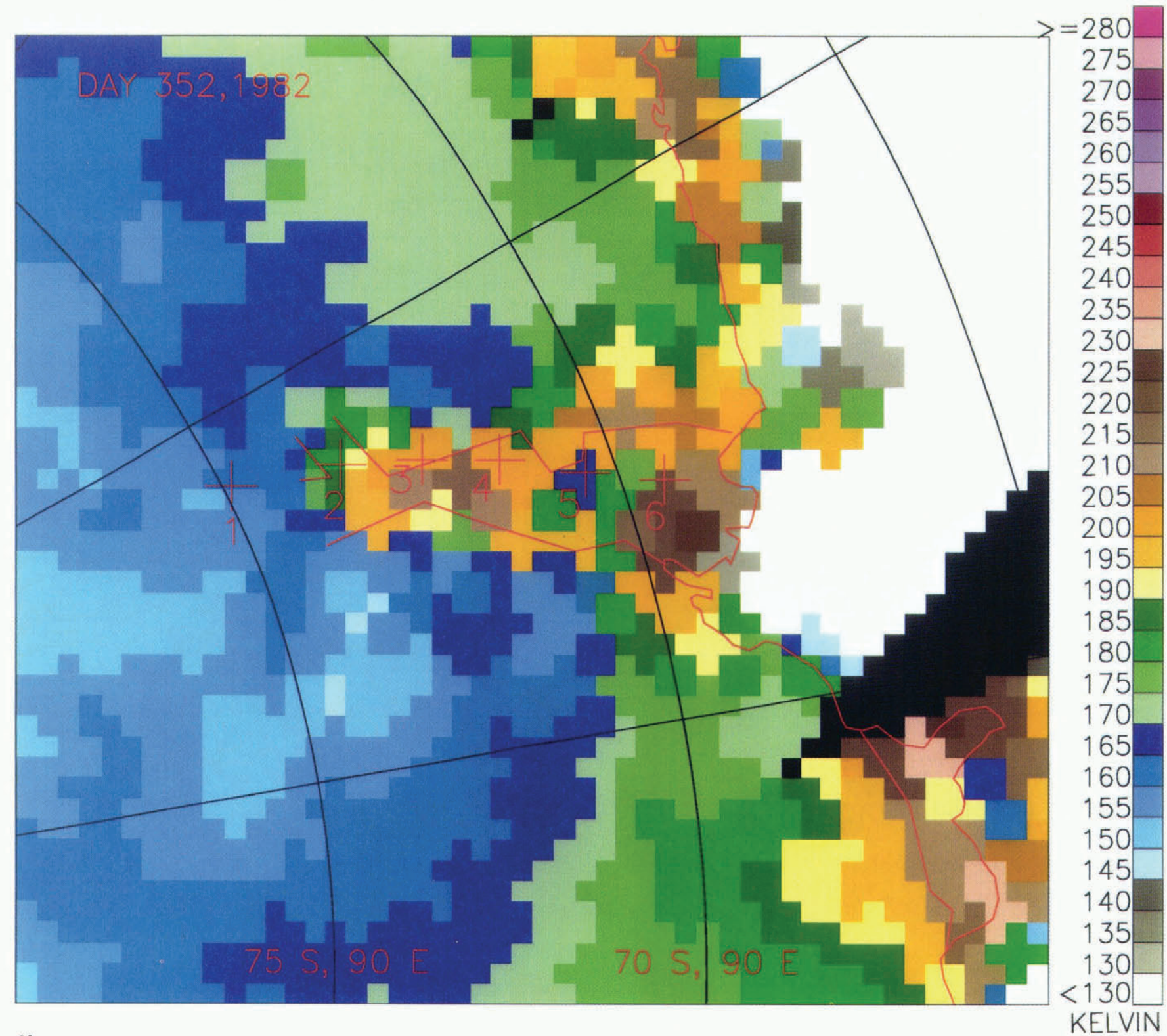

nearly the same in all zones. Using the equation $T_{\mathrm{b}}=\epsilon T_{\mathrm{p}}$ (where $T_{\mathrm{p}}$ is the physical temperature), the maximum value of $T_{\mathrm{b}}$ corresponding to a wet-firn emissivity of 0.9 is about $245 \mathrm{~K}$. Therefore, the rise in $T_{\mathrm{b}}$ with melting ranges from about 70 to $10 \mathrm{deg}$, corresponding to the $0.65-0.85$ range in emissivity of dry firn.

Consequently, some possible criteria, which could be useful for detection of melting in microwave brightness temperatures, are: (1) a rise of $T_{\mathrm{b}}$ above a fixed threshold, (2) a rise of $T_{\mathrm{b}}$ by a fixed amount above the expected local average summer value in the absence of melting, and (3) a rise of $T_{\mathrm{b}}$ by a fixed amount above the local mean annual $T_{\mathrm{b}}$. Thresholds for the second and third criteria would vary spatially, depending mainly on the microwave emissivity of the dry firn, and would allow a more sensitive detection of melt, as discussed below.

Figure 1 shows $T_{\mathrm{b}}$, at $1.5 \mathrm{~cm}$ wavelength and horizontal polarization, on the Amery Ice Shelf and the surrounding ice sheet during the onset of melting in December 1982. The time interval between each of the three maps is $10 \mathrm{~d}$. The field-of-view of the SMMR instrument is $55 \mathrm{~km}$ at $1.5 \mathrm{~cm}$ wavelength, and the data are mapped into approximately $30 \mathrm{~km}$ square pixels, which are visible in the figure. Therefore, each data pixel represents the average firn conditions over about $3000 \mathrm{~km}^{2}$, even though the data are mapped into $900 \mathrm{~km}^{2}$ pixels. Although the emissivities of wet firn at horizontal and vertical polarizations are nearly equal, the emissivity of dry firn at horizontal polarization is significantly lower than at vertical polarization. Therefore, horizontal polarization is used, because the increase in $T_{\mathrm{b}}$ with melting is larger at horizontal than at vertical polarization.

For the three scenes shown in Figure 1, the $T_{\mathrm{b}}$ is given in Table 1 at six locations labeled in the figure: on the ice sheet (point 1), upper Lambert Glacier (point 2), lower Lambert Glacier (point 3), the grounding line (point 4), central Amery Ice Shelf (point 5) and lower Amery Ice Shelf at $100 \mathrm{~km}$ from the shelf front (point 6 ). On Julian day 342 (8 December 1982), there is no indication of melting in the $T_{\mathrm{b}}$ map. On Julian day 352, the $T_{\mathrm{b}}$ increased by $18 \mathrm{deg}$ or more at locations $2-6$ (upper Lambert Glacier to lower Amery Ice Shelf), with the largest increases at points 4 and 6 but no increase at location 1 (on the ice sheet). Although the $T_{\mathrm{b}}$ increases observed at all locations $2-6$ suggest some melting on day 


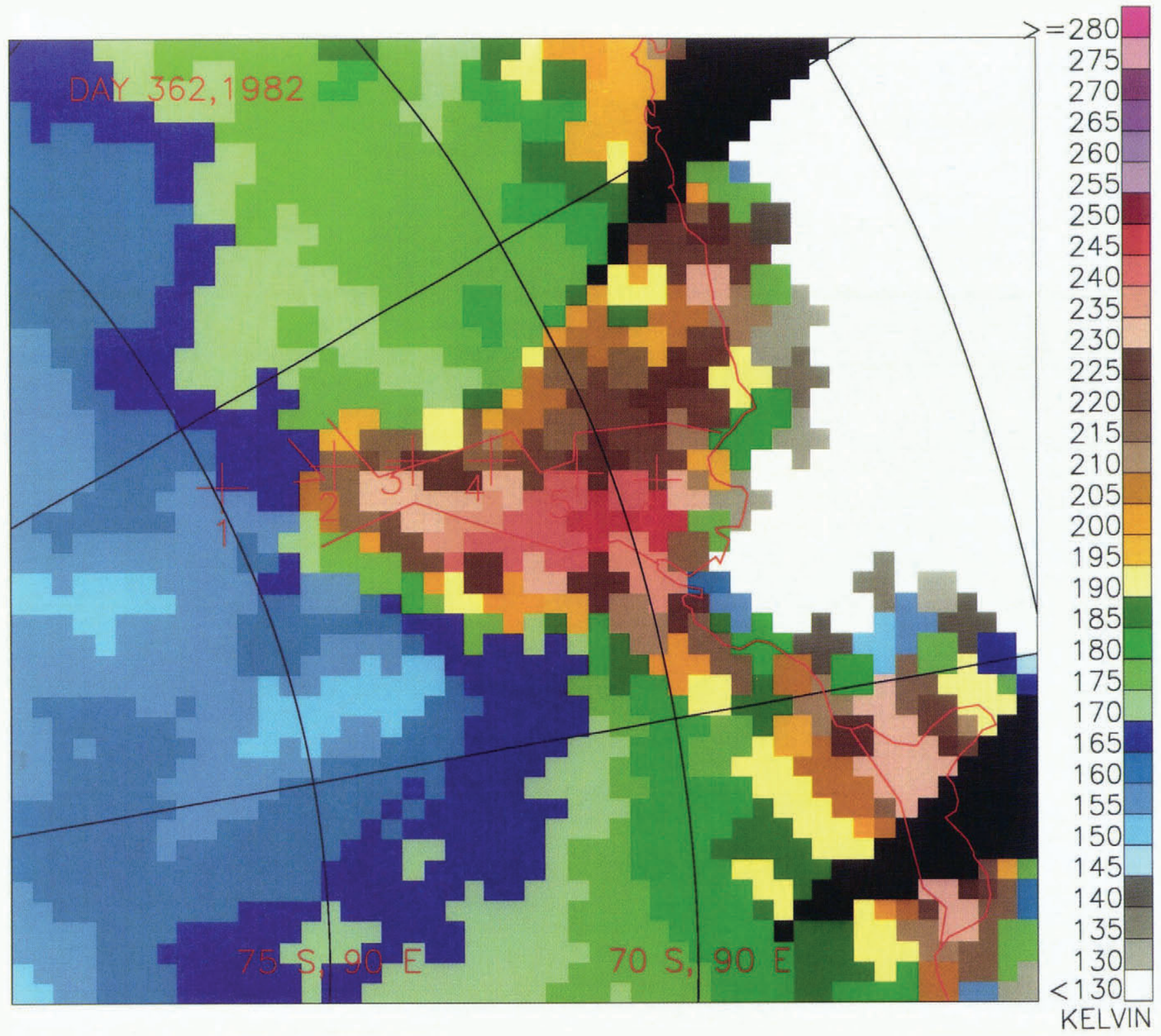

$1 c$

352 , the smaller increases of about $20 \mathrm{deg}$ at locations 2 and 5 are not clear indications of melting, because the winter to summer change in $T_{\mathrm{b}}$ (due to the seasonal change in physical temperature of the firn in the absence of melting) is also about $20 \mathrm{deg}$. By Julian day 362 , locations 2-6 have increases of about $40 \mathrm{deg}$ or more, clearly indicating a rise caused by melting.

On day 362, marked increases are evident over the entire ice shelf, appearing somewhat larger on the eastern side of the shelf. Also, large $T_{\mathrm{b}}$ increases indicative of melting are observed on the ice sheet surrounding the ice shelf to an elevation of about $1800 \mathrm{~m}$. As shown in the following analysis for 9 years, the extension of surface melting as far inland as location 2 (upper Lambert Glacier), as observed during day 362 of 1982, was unusual. During the summer of 1982/83, melting in other parts of Antarctica was also above average.

As previously noted, a sensitive criterion for melting

Table 1. Brightness temperatures at six locations extending inland from the front of the Amery Ice Shelf on three days in December 1982

\begin{tabular}{ccccccc}
\hline $\begin{array}{c}\text { Julian } \\
\text { day } \\
1982\end{array}$ & 1. Ice sheet & $\begin{array}{c}\text { 2. Upper } \\
\text { Lambert Glacier }\end{array}$ & $\begin{array}{c}\text { 3. Lower Lambert } \\
\text { Glacier }\end{array}$ & 4. Grounding line & 5. Central ice shelf & $\begin{array}{c}\text { 6. Ice shelf } 100 \mathrm{~km} \\
\text { from front }\end{array}$ \\
\hline 342 & $157 \mathrm{~K}$ & $173 \mathrm{~K}$ & $190 \mathrm{~K}$ & $165 \mathrm{~K}$ & $150 \mathrm{~K}$ & $175 \mathrm{~K}$ \\
352 & $T_{342}+0 \mathrm{~K}$ & $T_{342}+18 \mathrm{~K}$ & $T_{342}+25 \mathrm{~K}$ & $T_{342}+45 \mathrm{~K}$ & $T_{342}+20 \mathrm{~K}$ & $T_{342}+50 \mathrm{~K}$ \\
362 & $T_{342}+3 \mathrm{~K}$ & $T_{342}+39 \mathrm{~K}$ & $T_{342}+42 \mathrm{~K}$ & $T_{342}+80 \mathrm{~K}$ & $T_{342}+95 \mathrm{~K}$ & $T_{342}+70 \mathrm{~K}$
\end{tabular}



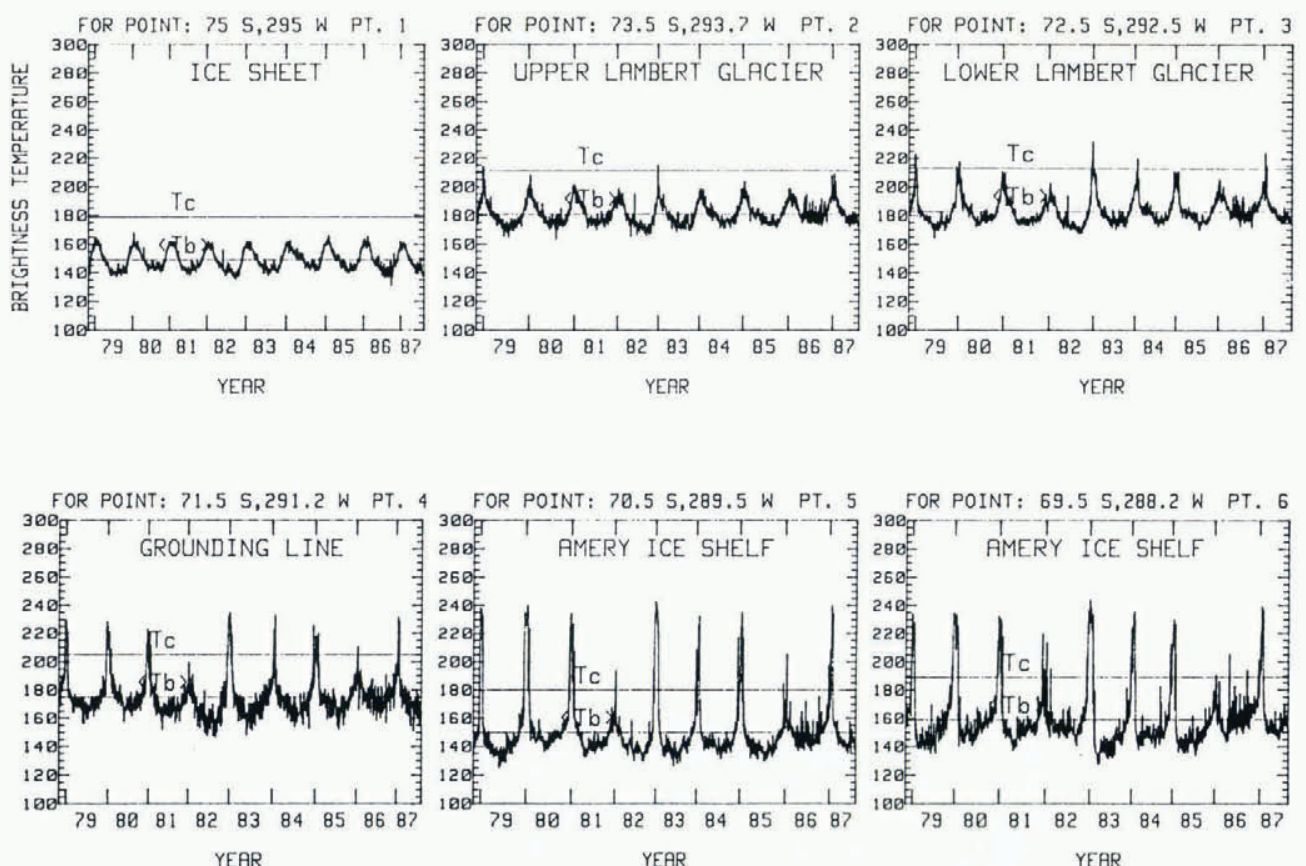

Fig. 2. The time series of $T_{\mathrm{b}} 1978-87$ at six locations on the Amery Ice Shelf and its vicinity (cf. Fig. 1). Also shown are the mean annual brightness temperatures, $\left\langle T_{\mathrm{b}}\right\rangle$, averaged over the 9 years. $T_{\mathrm{c}}$ is the threshold value of $T_{\mathrm{b}}$ taken to signify melting, and is chosen to be equal to $\left\langle T_{\mathrm{b}}\right\rangle$ plus $30 \mathrm{~K}$.

would be the rise of $T_{\mathrm{b}}$ by a fixed amount above the average summer $T_{\mathrm{b}}$ value expected in the absence of melting. Such a value could be determined by approximating the annual $T_{\mathrm{b}}$ cycle at each location and estimating the expected average value during the summer. The time series of $T_{\mathrm{b}}$ from 1978 to 1987 at the six locations on or near the Amery Ice Shelf (Fig. 1) are shown in Figure 2. Also shown are the mean annual brightness temperatures, $\left\langle T_{\mathrm{b}}\right\rangle$, averaged over the 9 years for each location. It can be seen that $\left\langle T_{\mathrm{b}}\right\rangle$ typically lies about $15 \pm 5 \mathrm{deg}$ below the average summer $T_{\mathrm{b}}$ that would be expected in the absence of melting. Therefore, a rise of $T_{\mathrm{b}}$ by a fixed amount above $\left\langle T_{\mathrm{b}}\right\rangle$ is used as a criterion for melting, because it is nearly equivalent to the rise above the non-melting summer value and is much simpler to calculate from the data. Consequently, the threshold value of $T_{\mathrm{b}}$ taken to signify melting is defined as $T_{\mathrm{c}}$, and is chosen to be equal to $\left\langle T_{\mathrm{b}}\right\rangle$ plus $30 \mathrm{~K}$.

The value of $T_{\mathrm{c}}$ equal to $\left\langle T_{\mathrm{b}}\right\rangle$ plus $30 \mathrm{~K}$, as shown in Figure 2, captures most of the apparent melting events and is sufficiently large to minimize false counts. The marked rise in $T_{\mathrm{b}}$ above $T_{\mathrm{c}}$ is clearly evident on the ice shelf at locations 5 and 6 . A $T_{\mathrm{b}}$ rise above $T_{\mathrm{c}}$ rarely occurs at location 2 on upper Lambert Glacier, occurs briefly in about half of the years at location 3 on lower Lambert Glacier, occurs every year except 1981/82 at the grounding line and occurs every year at the two iceshelf locations. No evidence of melting is seen in the $T_{\mathrm{b}}$ measured at location 1, on the ice sheet.

Increasing surface melting along the line from Lambert Glacier to the grounding line and toward the ice-shelf front is indicated by the increasingly longer duration of the rise of $T_{\mathrm{b}}$ above $T_{\mathrm{c}}$. The decreasing $\left\langle T_{\mathrm{b}}\right\rangle$ along this line also suggests that the firn has been subject to an increasing amount of surface melting toward the front. As noted previously, the process of melting and freezing increases the grain-size, which lowers the $T_{\mathrm{b}}$ of the refrozen firn. Consequently, the $T_{\mathrm{b}}$ signal associated with the onset of melting is stronger in areas where prior melting was greater. In some cases of unusually strong summer melting, such as location 6 in 1983, the $T_{\mathrm{b}}$ falls at the end of the melting season to a value that is lower than in other years.

The rise in $T_{\mathrm{b}}$ with melting would also be large in areas of normally dry firn with low accumulation rates and large grain-sizes near the surface, such as location 1. The $\left\langle T_{b}\right\rangle$ is very low at ice-sheet location 1 , because of the larger grain-sizes in the firn that are characteristic of dryfirn areas with low accumulation rates (Zwally, 1977). The annual $T_{\mathrm{b}}$ cycle of about $20 \mathrm{~K}$ at location 1 is due to the annual cycle of the physical temperature. The $\epsilon$ is about 0.63 . In the dry-firn zones, $\epsilon$ typically increases toward the coast, mainly due to the smaller grain-sizes where the accumulation rates are higher. The higher $T_{\mathrm{b}}$ on Lambert Glacier, compared to location 1 for example, suggests less microwave scattering in the firn, smaller grain-sizes, and presumably a higher accumulation rate on the glacier compared to the ice sheet upstream from the glacier. The $T_{\mathrm{b}}$ also increases toward the coast due to the higher $T_{\mathrm{p}}$ at lower elevations, but this is typically a secondary effect. In areas of normally dry firn that have high accumulations and small grain-sizes near the surface, such as northeastern Marie Byrd Land (cf. Fig. 3), the rise in $T_{\mathrm{b}}$ with melting would be small and more difficult to detect.

The increase of $T_{\mathrm{b}}$ as a function of the amount of moisture in the firn is also of interest. Measurements of snowpack on land showed that $T_{\mathrm{b}}$ rose to a maximum (saturation) value with moisture contents of only a few per cent in a thin surface layer. However, there is disagreement as to whether the moisture content required for saturation is in the range of about $10-20 \%$ or $2-5 \%$. Edgerton and others (1971) showed that $T_{\mathrm{b}}$ at $0.8 \mathrm{~cm}$ microwave wavelength reached a maximum with about 


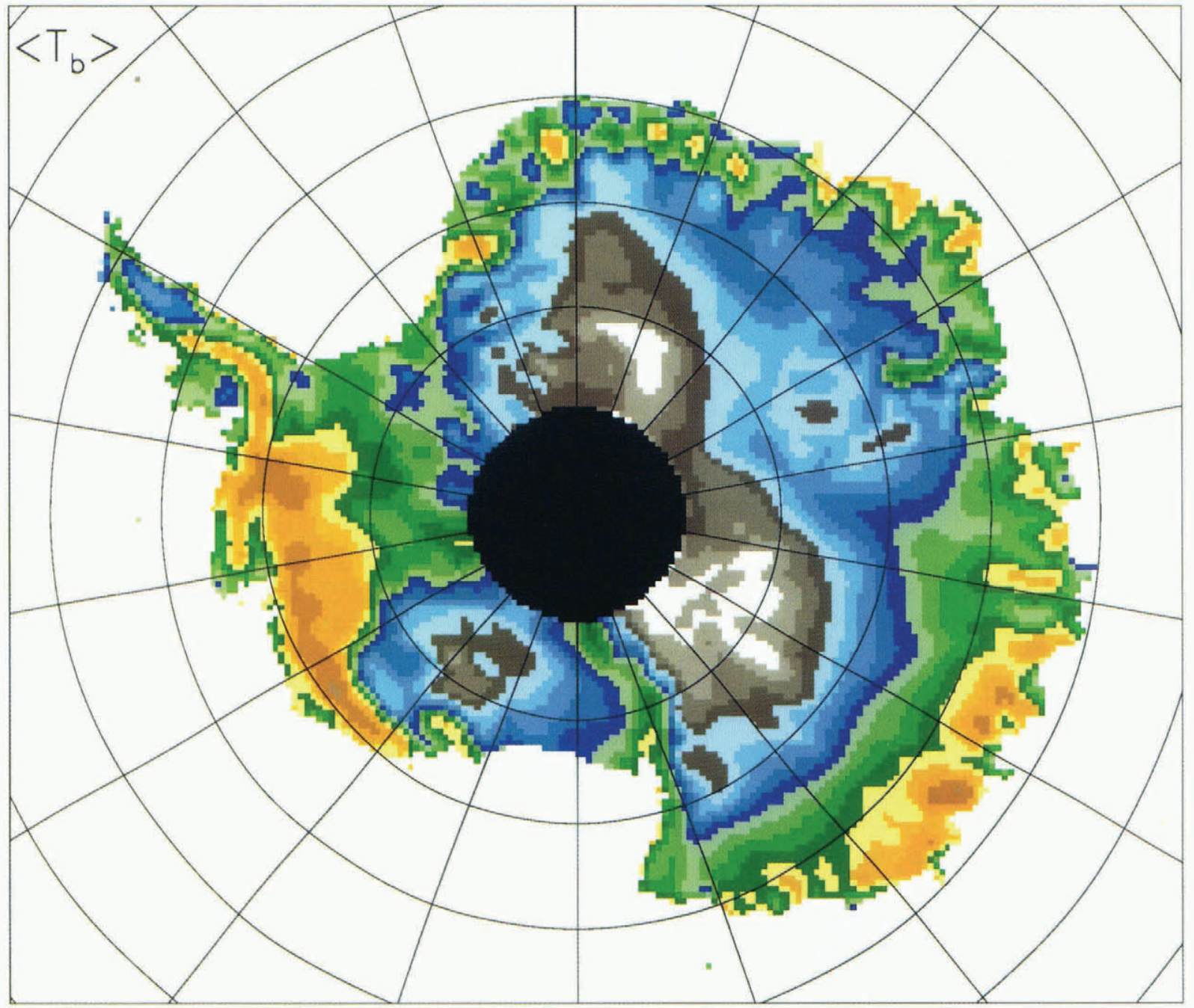

Fig. 3. Map of mean annual brightness temperatures, $\left\langle T_{\mathrm{b}}\right\rangle$, averaged over the 8 years from Nimbus-7 SMMR. The low $\left\langle T_{\mathrm{b}}\right\rangle$ on the Amery Ice Shelf, and on ice shelves in the Antarctic Peninsula and elsewhere, is caused by radiative scattering by the larger snow grains formed during summer melting. Other patterns are discussed in the text.

$15 \%$ moisture content, and at $2.2 \mathrm{~cm}$ wavelength reached a maximum with about $22 \%$ moisture content. Stiles and Ulaby (1980) showed $T_{\mathrm{b}}$ at $0.8 \mathrm{~cm}$ wavelength reaching a maximum at a lower moisture content of only about $1.5 \%$, whereas Davis and others (1987) showed a maximum at about $4 \%$. Davis and others (1987) also noted that the thickness of the wet layer grew to $3 \mathrm{~cm}$ as the moisture content reached 6\%. Furthermore, Edgerton and others (1971) noted that $T_{\mathrm{b}}$ remained high and did not appear to decrease as the moisture content increased enough to create a slush-like consistency.

For the purposes of a climate index, the actual value of the moisture content is not especially important. However, the characteristic of a monotonic increase of $T_{b}$ to a maximum without a subsequent decrease is very important, because it eliminates ambiguities between very wet and less wet firn. If, however, the moisture is not free to percolate and water collects in ponds or puddles, the $T_{\mathrm{b}}$ would be lowered by an amount that can be estimated. Where ponding occurs, such as in areas of the Amery Ice Shelf (personal communication from I. Allison), the observed $T_{\mathrm{b}}$ would be lowered in proportion to the area of the sensor field-of-view covered by ponds. Since the $T_{\mathrm{b}}$ of liquid water at $1.5 \mathrm{~cm}$ is about $130 \mathrm{~K}$, the $T_{\mathrm{b}}$ of an area with $20 \%$ ponds and $80 \%$ wet firn at $T_{\mathrm{b}}$ of $245 \mathrm{~K}$ would be about $222 \mathrm{~K}$, for example. Since the lowest $T_{\mathrm{c}}$ on the Amery Ice Shelf is less than about $200 \mathrm{~K}$ in the regions of intense melting, ponding would have to cover about $40 \%$ of the area of wet firn to reduce the observed $T_{\mathrm{b}}$ below $T_{\mathrm{c}}$. Therefore, in most places the area of ponded water in wet firn is unlikely to be sufficient to cause failure to indicate melting. In areas where the $T_{\mathrm{b}}$ 'is above $T_{\mathrm{c}}$, but below the $245 \mathrm{~K}$ characteristic of wet firn, the probable causes are either a mixture of melting and non-melting firn within the field-of-view, or an averaging of measurements from periods of melting and non-melting surface conditions, as well as the possibility of some ponding.

\section{GALGULATION OF SURFACE-MELT INDEX}

The duration and extent of melting are described by a 

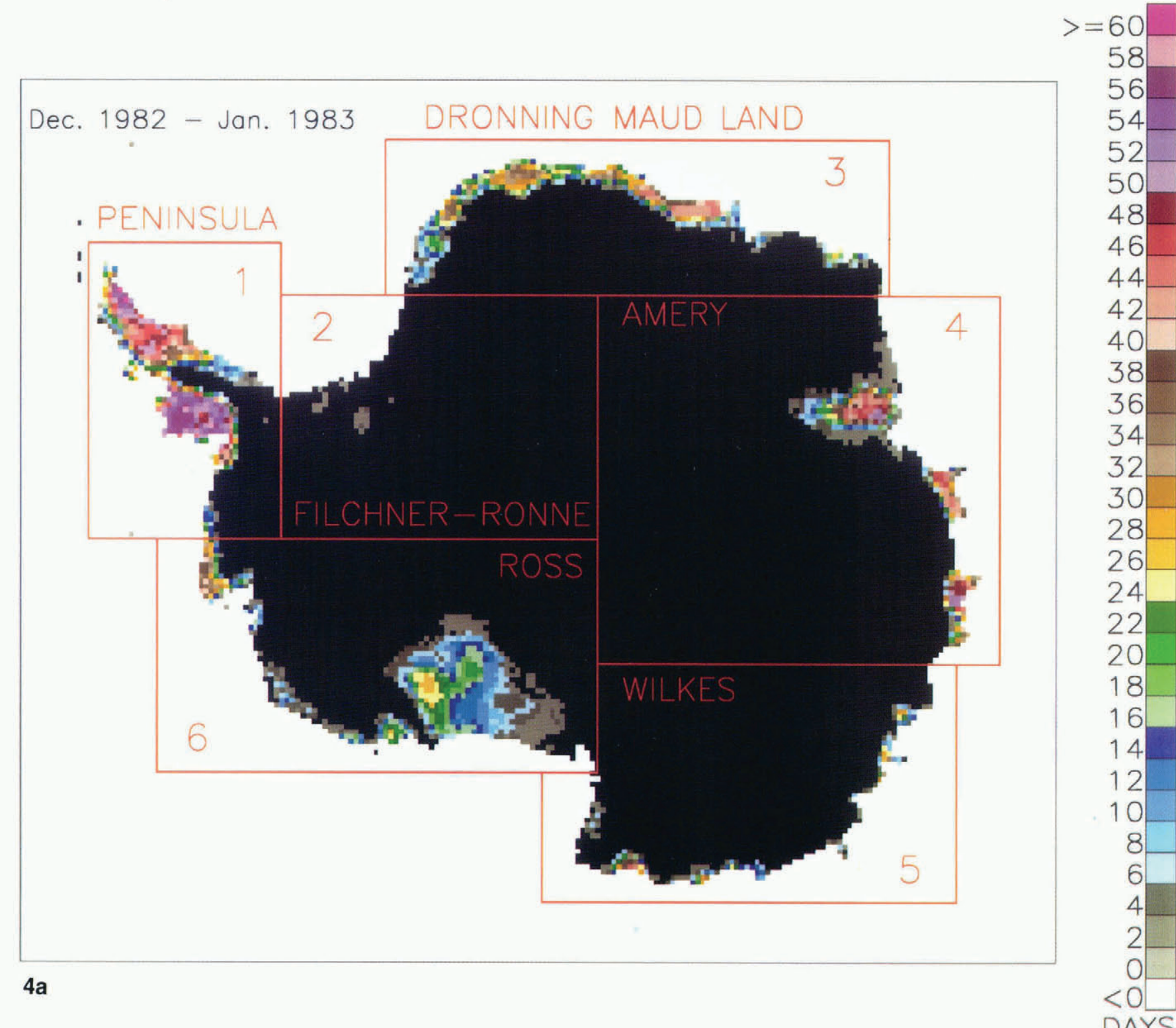

$4 a$

Fig. 4. Local surface melting (days per pixel) for (a) 1982/83, which is a summer with unusually high surface melting, and (b) 1983/84, which is a summer with below-average surface melting. Analysis regions are outlined. The surface melting shown on the Ross Ice Shelf in 1982/83 is unusual.

surface-melt index (in units of duration times area), which is calculated by adding the areas of the pixels in the brightness-temperature maps where melting occurs, over selected regions and periods of time. For each $30 \mathrm{~km} \times 30 \mathrm{~km}$ pixel in the daily maps, $T_{\mathrm{b}}$ increases of more than $T_{\mathrm{c}}=30 \mathrm{deg}$ above the annual-mean brightness temperature, $\left\langle T_{\mathrm{b}}\right\rangle$, are taken to indicate melting, as discussed in the previous section. The map of $\left\langle T_{\mathrm{b}}\right\rangle$ is shown in Figure 3. Each occurrence of melting was counted twice, because data were only collected by SMMR every other day. The consequent error caused by this adjustment for missing data should be very small, except possibly in regions of very infrequent and shortduration melting.

The duration of melting at each location (number of days per pixel) is shown in Figure 4 for 1982/83 and 1983/ 84 for the months of December and January. Most melting occurs in December and January. Also shown are the six regions selected for calculation of the melt index: (1) the Antarctic Peninsula, (2) the Filchner-Ronne Ice
Shelf region, (3) the Dronning Maud Land coast, (4) the East Antarctic coast including the Amery, West and Shackleton Ice Shelves, (5) the Wilkes Land coast, and (6) the Ross Ice Shelf region and the West Antarctic coast west of $90^{\circ} \mathrm{W}$. The melting is unusually large in the summer of $1982 / 83$ and smaller than average in the summer of $1983 / 84$. For $1982 / 83$, the index for all of Antarctica is $35.8 \times 10^{6} \mathrm{~d} \mathrm{~km}^{2}$ for November-February and $34.8 \times 10^{6} \mathrm{~d} \mathrm{~km}^{2}$ for December and January. Therefore, the daily average area with surface melting is $0.56 \times 10^{6} \mathrm{~km}^{2}$ during December and January, or about $4 \%$ of the continental area. In $1983 / 84$, the corresponding values are $17.0 \times 10^{6} \mathrm{~d} \mathrm{~km}^{2}$ for November-February and $15.0 \times 10^{6} \mathrm{~d} \mathrm{~km}^{2}$ for December and January, with a daily average of $0.24 \times 10^{6} \mathrm{~km}^{2}$ during December and January, or $2 \%$ of the continental area.

In both summers $1982 / 83$ and $1983 / 84$, some parts of the Larsen Ice Shelf, the northern Antarctic Peninsula, Alexander Island, and the ice shelves surrounding Alexander Island had surface melting throughout 


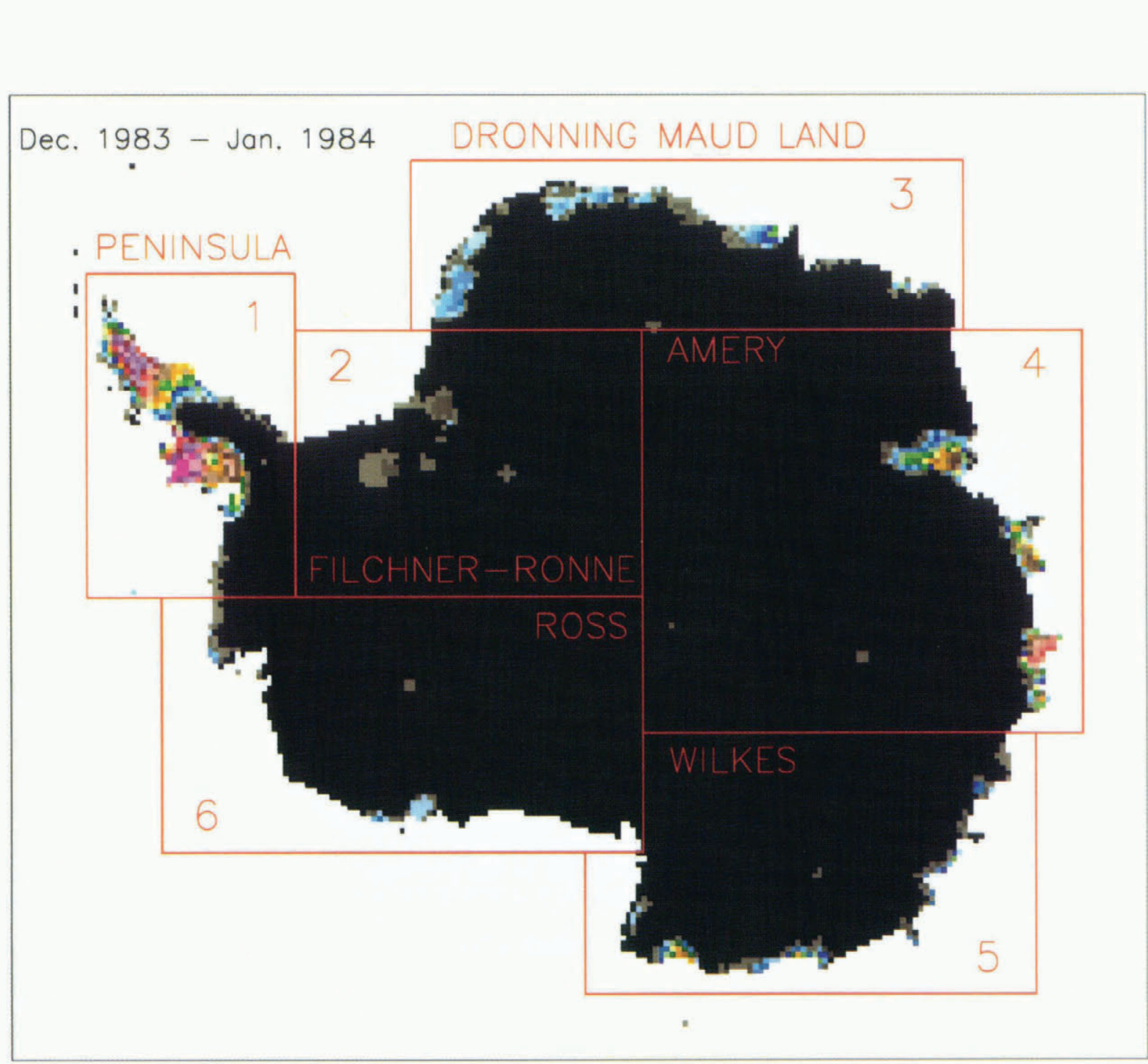

December and January. During the 1982/83 summer, above-average melting occurred in the Dronning Maud Land, Amery Ice Shelf, and Antarctic Peninsula regions, and an unusually large area of melting occurred on the Ross Ice Shelf.

\section{CORRELATION OF SURFACE-MELT INDEX AND TEMPERATURE}

The relationship between higher values of the surfacemelt index and the occurrence of temperatures above and near the melting point is examined, by comparing regional melt indices with monthly-average temperatures at selected stations (Jones and Limbert, 1988). The monthly-average station temperatures should represent the regional temperatures, $\left(T_{\mathrm{S}}\right)$ which affect the regional surface melting and therefore the calculated melt index. In contrast, daily temperatures should be more closely related to local and short-term variations in melting. The derived relationship between melt index and temperature shows how melting increases with increasing summer temperature, and demonstrates the validity of the melt index.

The Australian Davis Station at $68.6^{\circ} \mathrm{S}, 78^{\circ} \mathrm{E}$ is only about $250 \mathrm{~km}$ northeast of the locations on the Amery Ice Shelf where the most extensive melting in the region occurs. The surface-melt index in Figure 5 clearly increases as summer temperatures increase. The linear fit between the melt index and monthly-average station temperature indicates a melt-index increase by $0.67 \times 10^{6} \mathrm{~d} \mathrm{~km}^{2}$ per degree of temperature rise. It also implies that the summer melting is negligible when the average monthly temperature at Davis Station is less than $-2.3^{\circ} \mathrm{C}$.

At the smaller values of the melt index, the relationship to temperature appears to be linear. However, the increase of the melt index as a function of temperature is greater for December than it is for January, when the index value is generally largest. At larger values of the index, a non-linear relation should be expected, because a maximum in the melt index must be reached when the entire area experiences melting every day. Although melting over all of this particular region is extremely unlikely, melting of much of the area below an elevation of several hundred meters is very likely during December and January. Such melting on the Amery Ice Shelf is shown in Figure $4 \mathrm{a}$ by the pixels with more than $30 \mathrm{~d}$ of surface melting. For increasingly higher temperatures, additional increases in melt area would occur at a much 


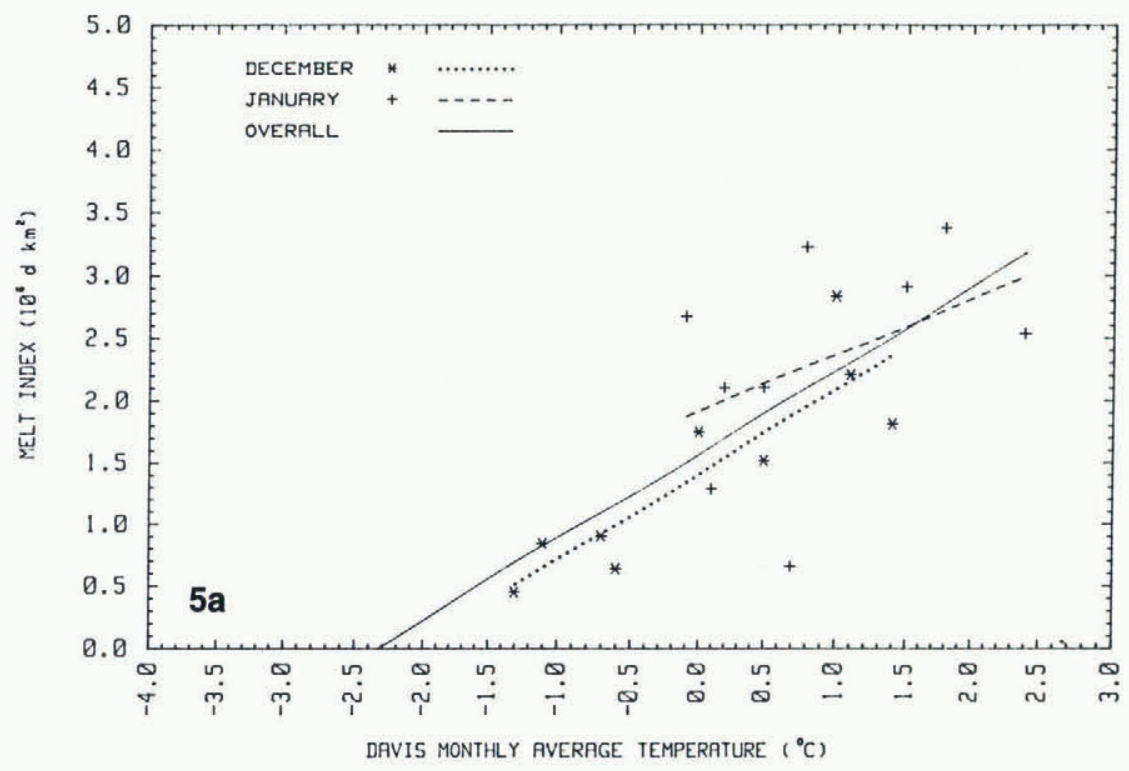

Fig. 5. Correlations between the calculated melt indices and monthly-average station temperatures (cf. Table 2), December and January 1978-88, for (a) Davis Station and the Amery Ice Shelf region, (b) Syowa Station and Dronning Maud Land region, (c) Rothera Point and the Antarctic Peninsula region, and (d) Casey Station and Wilkes Land region.
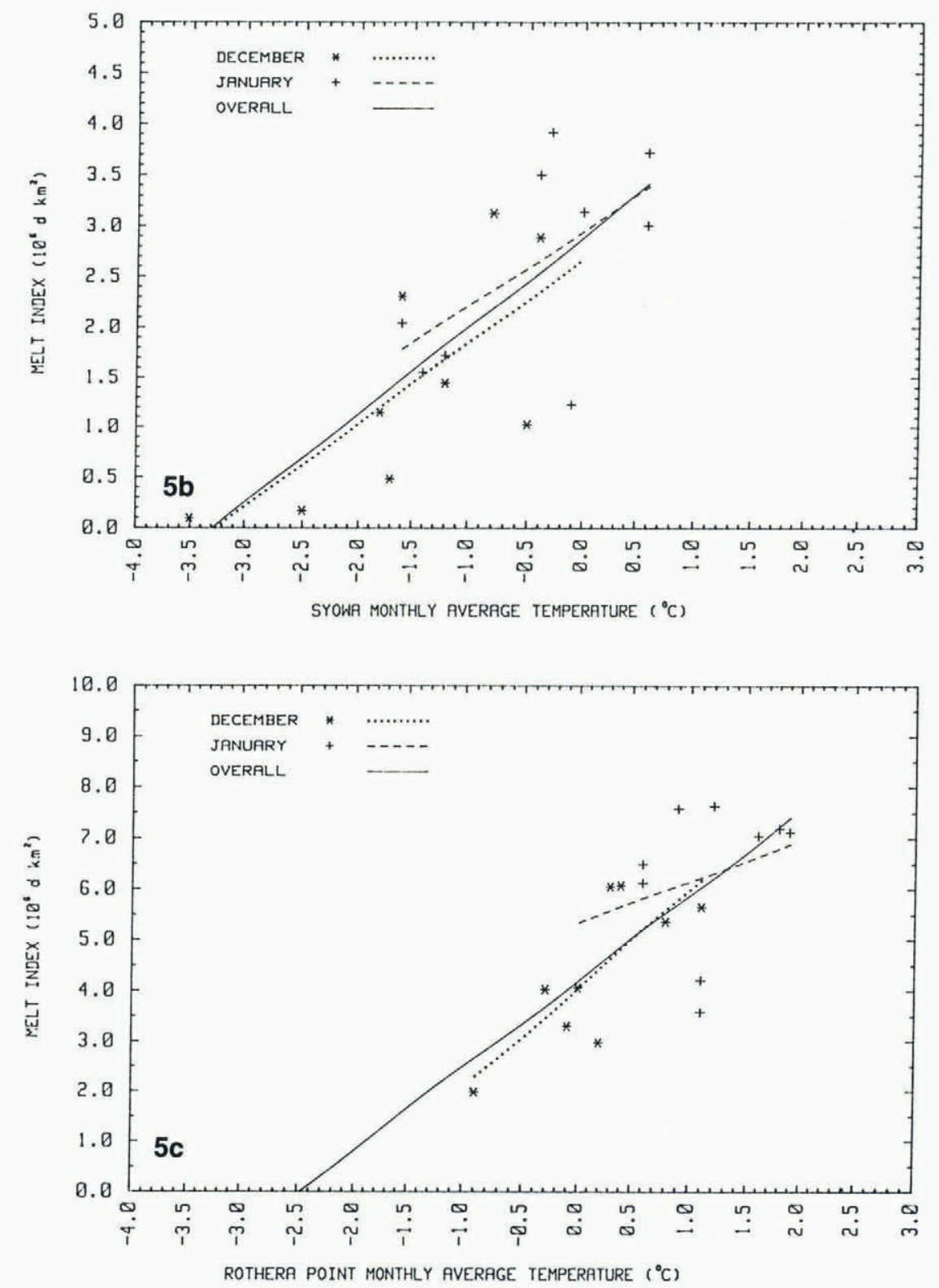


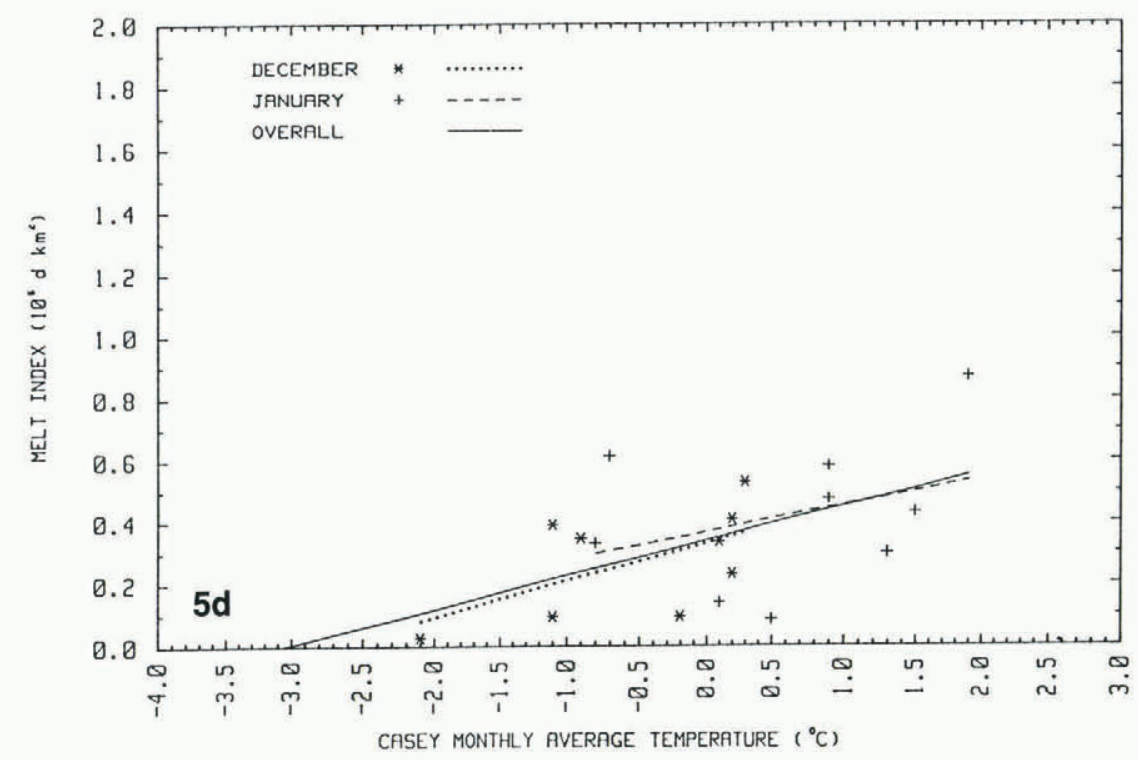

slower rate, because the inland spread of melting is retarded by the large surface slopes of the ice sheet above several hundred meters elevation.

Furthermore, inter-annual departures from a linear relation, as suggested by the scatter in the data, might also be expected, because melting is inherently a non-linear function occurring only above a threshold temperature. For example, for a month with unusually cold temperatures during part of the month, and with a significant period of melting, the average temperature might be below normal while the amount of melting is above normal.

Some of the scatter may also be caused by variations in the spatial extent of heating that is caused by katabatic winds. Melt patterns that appear to be related to katabatic winds are illustrated in some of the daily $T_{\mathrm{b}}$ maps. For example, on Julian day 352 of 1982 (Fig. 1b), melting is indicated on the northern part of the Amery Ice Shelf, extending southeastward from point 6 to
Kreitser Glacier (and adjacent outflow glaciers) and onto the ice sheet to about $1000 \mathrm{~m}$ elevation. Similar melting is indicated on lower Lambert Glacier down to the grounding line (points 3 and 4), but not on the middle part of the ice shelf at point 5 . Since katabatic winds are channeled by the topography on such outlet glaciers, the corresponding patterns of melting on day 352 are likely to be affected by katabatic-wind heating of the surface. In contrast, melting associated with warm synoptic-scale meteorological conditions should be more uniform over larger areas at the same surface elevation (e.g. Julian day 362 in Figure 1c).

Similar relationships between the melt index and summer temperatures are found in the other regions (Fig. 5b-d; Table 2), except in the Ross and Filchner-Ronne Ice Shelf regions where melting is too infrequent. The linear correlation coefficients between the melt indices and the monthly-average station temperatures are greater than 0.7 , except in the Wilkes Land region where the

Table 2. Relation between regional surface-melt indices and monthly-average station temperatures $\left(T_{\mathrm{8}}\right) . R$ is the linear correlation coefficient

\begin{tabular}{|c|c|c|c|c|}
\hline Region & Station & $\begin{array}{l}\text { Melt threshold } \\
\qquad{ }^{\circ} \mathrm{C}\end{array}$ & $\begin{array}{l}\text { Melt index } \\
10^{6} \mathrm{~d} \mathrm{~km}^{2}\end{array}$ & $R$ \\
\hline $\begin{array}{l}\text { Amery } \\
\text { Ice Shelf }\end{array}$ & $\begin{array}{l}\text { Mawson, } \\
67.6^{\circ} \mathrm{S}, 62.9^{\circ} \mathrm{E} \\
\text { Davis, } \\
68.6^{\circ} \mathrm{S}, 78.0^{\circ} \mathrm{E} \\
\text { Mirny, } \\
66.5^{\circ} \mathrm{S}, 93.0^{\circ} \mathrm{E}\end{array}$ & $\begin{array}{l}-2.3 \\
-2.3 \\
-4.1\end{array}$ & $\begin{array}{l}2.0+0.8 T_{\mathrm{s}} \\
1.6+0.7 T_{\mathrm{s}} \\
3.7+0.9 T_{\mathrm{s}}\end{array}$ & $\begin{array}{l}0.85 \\
0.72\end{array}$ \\
\hline $\begin{array}{l}\text { Dronning } \\
\text { Maud } \\
\text { Land }\end{array}$ & $\begin{array}{l}\text { Syowa, } \\
69.0^{\circ} \mathrm{S}, 19.6^{\circ} \mathrm{E}\end{array}$ & -3.3 & $2.9+0.9 T_{\mathrm{s}}$ & 0.76 \\
\hline $\begin{array}{l}\text { Antarctic } \\
\text { Peninsula }\end{array}$ & $\begin{array}{l}\text { Rothera Point, } \\
67.6^{\circ} \mathrm{S}, 68.1^{\circ} \mathrm{W}\end{array}$ & -2.5 & $4.2+1.7 T_{\mathrm{s}}$ & 0.72 \\
\hline $\begin{array}{r}\text { Wilkes } \\
\text { Land }\end{array}$ & $\begin{array}{l}\text { Casey, } \\
66.3^{\circ} \mathrm{S}, 110.5^{\circ} \mathrm{E}\end{array}$ & -3.5 & $0.3+0.1 T_{\mathrm{s}}$ & 0.53 \\
\hline
\end{tabular}


melting is small. In the Amery Ice Shelf region, the relationships are nearly the same for Davis and Mawson Stations, but the colder temperatures at Mirny are reflected in the lower value of the threshold temperature (the monthly-average station temperature above which regional surface melting usually occurs). In the Antarctic Peninsula region, the slope of the index-temperature relation is about twice as large as for the Amery Ice Shelf and Dronning Maud Land regions. In the Wilkes Land region, it is only about one-tenth as large. Therefore, for each degree of increase in Antarctic summer temperatures, about as much area of melting is added in the Antarctic Peninsula as in the rest of Antarctica.

\section{REGIONAL AND TEMPORAL VARIATIONS IN SURFACE-MELT INDEX}

The calculated surface-melt index for each of the six selected regions and their sum are plotted in Figure 6, for the nine summers from $1978 / 79$ to $1986 / 87$, for the months of November, December, January, and February. As noted before, most Antarctic surface melting occurs during December and January. In most cases, the index indicates more melt in January. The indices for November and February are typically about $5-10 \%$ as large as for the other two summer months.

The largest amount of melting occurs in the Antarctic Peninsula region, followed by the Dronning Maud Land and Amery Ice Shelf regions with nearly equal amounts of melting. In some years, the amount of melting in the Ross Ice Shelf region is as large as in the Dronning Maud Land and Amery Ice Shelf regions, but during several of the summers almost no melting is observed in the Ross Ice Shelf region. A lesser amount of melting occurs in the Wilkes Land region, but it is more consistent from year to year. In the Filchner-Ronne region, the melt index is very small ( $<0.3 \times 10^{6} \mathrm{~d} \mathrm{~km}^{2}$ per month), but this region is the only one that shows an increase in the melt index during the nine summers.

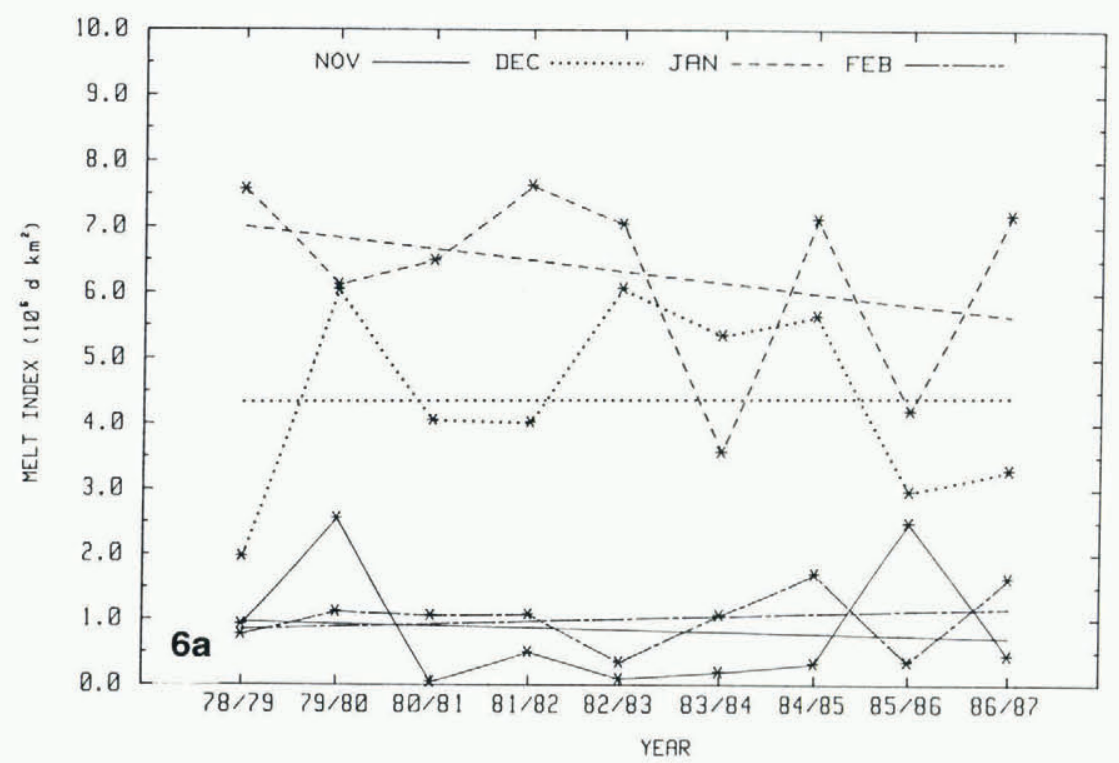

Fig. 6. Calculated melt indices for nine summers for the months of November, December, January, and February for six regions and overall: (a) the Antarctic Peninsula, (b) Filchner-Ronne Ice Shelf, (c) the Dronning Maud Land coast, (d) the East Antarctic coast including the Amery, West and Shackleton Ice Shelves, (e) the Wilkes Land coast, $(f)$ the Ross Ice Shelf region and the West Antarctic coast west of $90^{\circ} \mathrm{W}$, and $(\mathrm{g})$ overall.

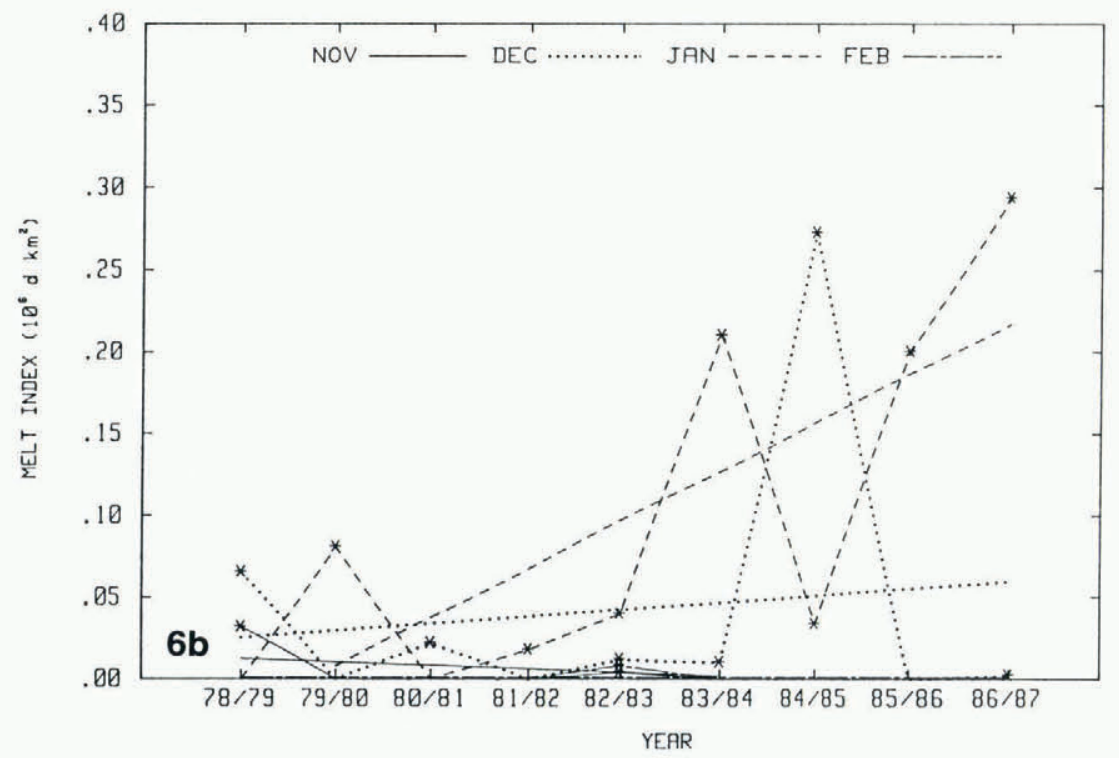



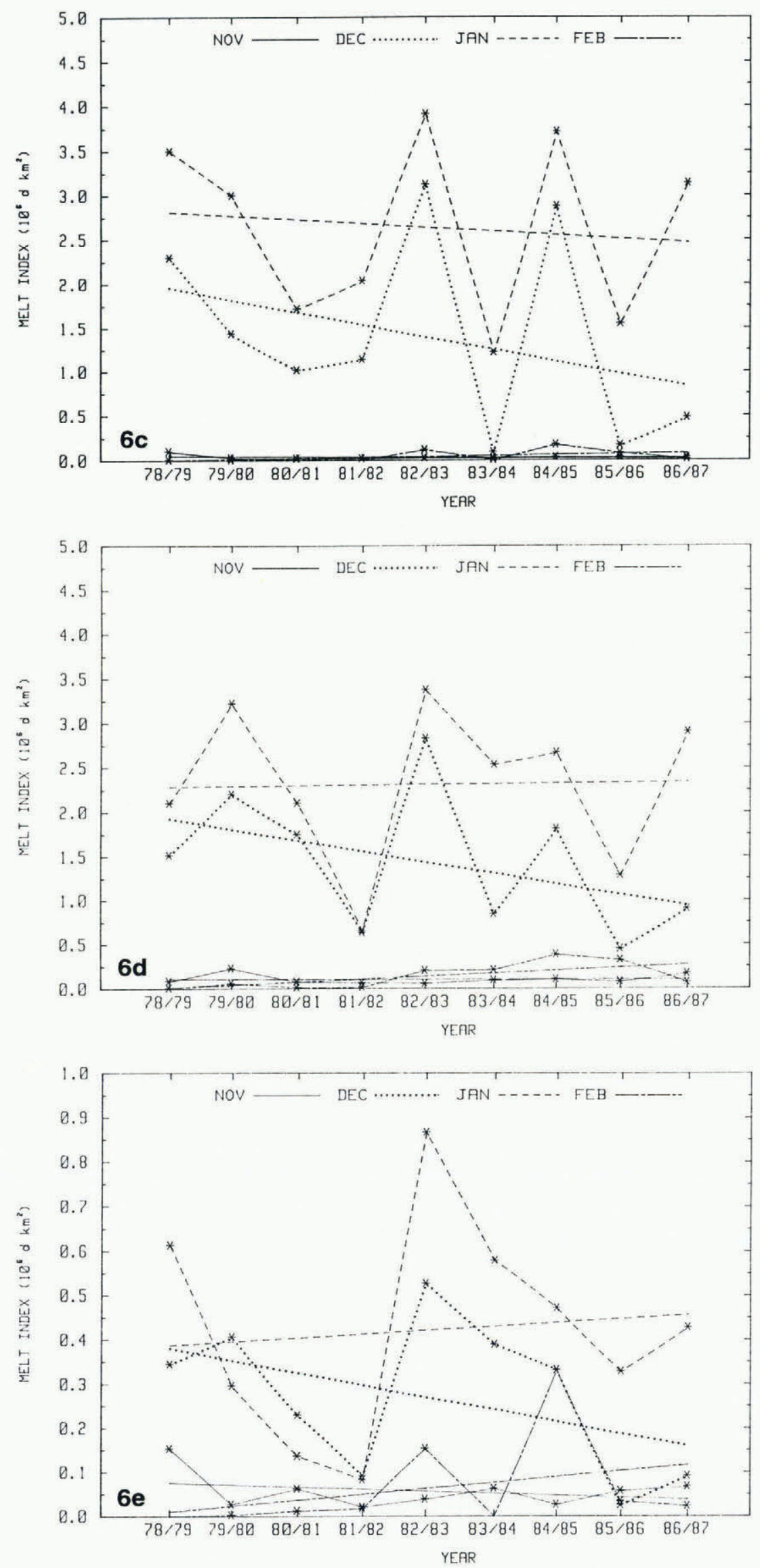

The melt index for all of Antarctica in Figure $6 \mathrm{~g}$ shows a decreasing trend on the basis of the linear fit for the months of November $\left(-0.04 \times 10^{6} \mathrm{~d} \mathrm{~km}^{2} \mathrm{year}^{-1}\right)$, December $\left(-0.26 \times 10^{6} \mathrm{~d} \mathrm{~km}^{2}\right.$ year $\left.^{-1}\right)$ and January $\left(-0.39 \times 10^{6}\right.$ $\left.\mathrm{d} \mathrm{km}^{2} \mathrm{year}^{-1}\right)$. A small increase is indicated for the month

of February $\left(0.11 \times 10^{6} \mathrm{~d} \mathrm{~km}^{2}\right.$ year $\left.^{-1}\right)$. The 9 year average values of the melt index are $1.12 \times 10^{6} \mathrm{dkm}^{2}$ for November, $8.56 \times 10^{6} \mathrm{~d} \mathrm{~km}^{2}$ for December, $13.00 \times 10^{6}$ $\mathrm{d} \mathrm{km}$ for January, $1.32 \times 10^{6} \mathrm{~d} \mathrm{~km}^{2}$ for February and $24.00 \times 10^{6} \mathrm{~d} \mathrm{~km}^{2}$ for the entire summer. The overall 

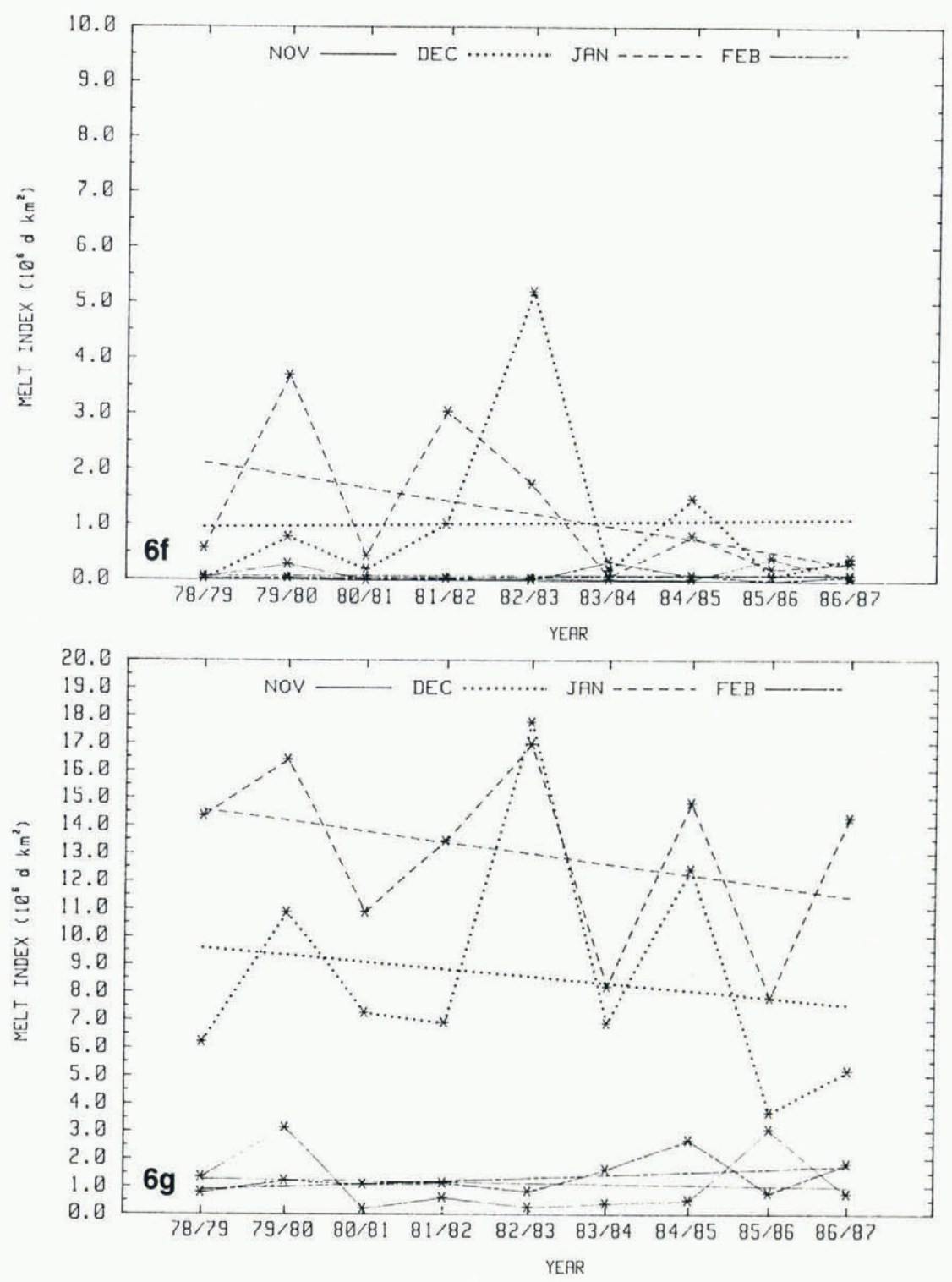

melt index for Antarctica for the entire summer (Fig. 7) shows a decrease of $-0.58 \times 10^{6} \mathrm{~d} \mathrm{~km}^{2}$ year ${ }^{-1}$, or $-2.4 \%$ per year. However, the inter-annual variability is very large. The year-to-year fluctuation is three times as large as the 9 year decrease inferred from the linear fit. Also, the

peak-to-peak difference, between the largest overall melt index of $35.8 \times 10^{6} \mathrm{~d} \mathrm{~km}^{2}$ in 1982/83 and the smallest of $15.3 \times 10^{6} \mathrm{~d} \mathrm{~km}^{2}$ in $1985 / 86$, is $20.5 \times 10^{6} \mathrm{~d} \mathrm{~km}^{2}$, or $85 \%$ of the average value.

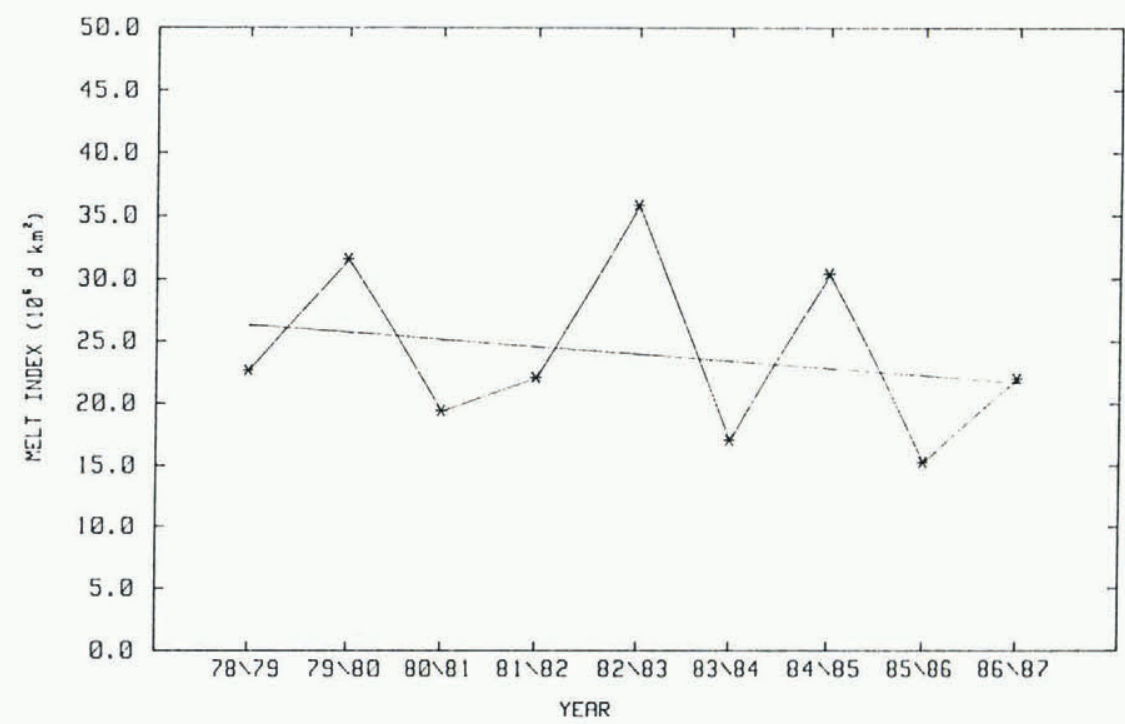

Fig. 7. Calculated melt indices for nine summers, November-February 1978-87, for all of the Antarctic. Linear fit shows a tendency for decreased melting, but the trend is not significant because of the large inter-annual variability. 


\section{CONCLUSIONS}

The physical basis for the observation of surface melting on ice sheets by satellites is the marked increase in the passive-microwave brightness temperature of firn that occurs with small amounts of moisture in the top few centimeters. A surface-melt index is derived and calculated for Antarctica for nine summers from 1978/79 to $1986 / 87$. Comparison between the calculated regionalmelt indices and selected-station air temperatures shows definitive correlations. The correlations suggest that the surface melting in Antarctica increases about $3.5 \times$ $10^{6} \mathrm{~d} \mathrm{~km}^{2}$ per degree of summer temperature increase. Also, surface melting usually occurs when the monthly average temperature is above about -4 to $-2^{\circ} \mathrm{C}$.

The 9 year average melt index calculated for Antarctica is $24 \times 10^{6} \mathrm{~d} \mathrm{~km}^{2}$. Antarctic surface melting was most intensive in the $1982 / 83$ summer $\left(35.8 \times 10^{6} \mathrm{~d} \mathrm{~km}^{2}\right)$ and least intensive in the $1985 / 86$ summer $\left(15.3 \times 10^{6} \mathrm{~d} \mathrm{~km}^{2}\right)$. Most melting occurs during December and January, with more in January. Linear-least-squares slopes are mostly negative (i.e. decreased surface melting in later years), but the significance of any inferred trend is undetermined because of the large inter-annual variability. In most cases, the melt index alternates from low to high from one year to the next, suggesting a biannual oscillation in the melt conditions during this period.

\section{REFERENCES}

Alley, R. B. and C. R. Bentley. 1988. Ice-core analysis on the Siple Coast of West Antarctica. Ann. Glaciol., 11, 1-7.
Chang, T. C. and P. Gloersen. 1975. Microwave emission from dry and wet snow. In Rango, A., ed. Operational applications of satellite snowcover observations. Washington, DC, National Aeronautics and Space Administration, 399-407. (NASA SP-391.)

Davis, R.E., J. Dozier and A.T.C. Chang. 1987. Snow property measurements correlative to microwave emission at $35 \mathrm{GHz}$. IEEE Trans. Geosci. Remote Sensing, GE-25(6), 751-757.

Edgerton, A. T. and 6 others. 1971. Microwave emission characteristics of natural materials and the environment. (Final report 9016R-8, ONR contract N00014-70C-0351. Aerojet General, El Monte, CA.)

Giovinetto, M.B. 1964. Distribution of diagenetic snow facies in Antarctica and in Greenland. Arctic, 17(1), 32-40.

Gloersen, P., W.J. Campbell, D.J. Cavalieri, J. C. Comiso, C. L. Parkinson and H.J. Zwally. 1992. Arctic and Antarctic sea ice, 19781987: satellite passive-microwave observations and analysis. Washington, DC, National Aeronautics and Space Administration. (NASA SP-511.)

Jones, P.D. and D. W. Limbert. 1988. Antarctic surface temperature and pressure data. Oak Ridge, TN, Oak Ridge National Laboratory. (Report NDPO32.)

Mercer, J. H. 1978. West Antarctic ice sheet and $\mathrm{CO}_{2}$ greenhouse effect: a threat of disaster. Nature, 271(5643), 321-325.

Paterson, W.S. B. 1984. Present and future melting on Antarctic ice shelves. In Van Loon, H., ed. Environment of West Antarctica: potential $\mathrm{CO}_{2}$-induced changes. Washington, DC, NAS Press, 140-154.

Stiles, W.H. and F. T. Ulaby. 1980. The active and passive microwave response to snow parameters: 1. Wetness. J. Geophys. Res., 85(C2), 1037-1044.

Stuiver, M., G. H. Denton, T. J. Hughes and J. L. Fastook. 1981. History of the marine ice sheet in West Antarctica during the last glaciation: a working hypothesis. In Denton, G. H. and T.J. Hughes, eds. The last great ice sheets. New York, etc., John Wiley and Sons, 319-436.

Zwally, H.J. 1977. Microwave emissivity and accumulation rate of polar firn. J. Glaciol., 18(79), 195-215.

Zwally, H.J. and P. Gloersen. 1977. Passive microwave images of the polar regions and research applications. Polar Rec., 18(116), 431-450.

The accuracy of references in the text and in this list is the responsibility of the authors, to whom queries should be addressed. 